\title{
Reading And Writing: Development Of Project-based Learning (PBL) Approach
}

\author{
Dian Rachmawati \\ University of MuhammadiyahGresikEnglish \\ Education Department \\ Gresik, Indonesia \\ didirachmawati@gmail.com
}

\author{
Candra Candra Hadi Asmara \\ University of Muhammadiyah Gresik \\ English Education Department \\ Gresik, Indonesia \\ cha_ragil77@yahoo.com
}

\begin{abstract}
This article describes a digital flipping book application in developing integrated reading and writing materials using RELIFLASH application at State Junior High School of 4 Gresik. RELIFLASH which is an abbreviation of CorelDraw, Adobe Illustrator, and Adobe Flash is a commercial software that is used in developing this digital flipping book application. This study is a research and development design. The instruments to collect the data are interview and questionnaire through English teacher and 61 students in eighth grade, then they were implemented to English teacher and 28 students from eighth grade. The aims of this study are to define the best way to give learners the various media for studying English, especially in listening and reading by integrating both of the materials in a digital flipping book application and to investigate whether or not the use of the digital flipping book can help the students' problem in listening and reading. This application consists of materials and exercises which use project-based learning approach to design exercises according to PBL steps; essential question, plan, schedule, monitor, assess, and evaluate. This application can be operated by students in their mobile sources; laptop or PC, although they do not have software which is used to make digital flipping book. The results of this study are the digital flipping book application is well operated and students agreed this application used in learning process.
\end{abstract}

Keywords-integrated material; reading; writing; RELIFLASH Application; project-based learning

\section{INTRODUCTION}

Technology and education in this era are really close, students in this era use technology as their need to support their learning. The researcher creates an application to support teacher and students in learning activity. In this case, the researcher's concern is in reading and writing skill as

receptive and productive skill. The curriculum that is used by teacher in the classroom is different with the application curriculum and the researcher wants to help teacher to use their times in teaching reading and writing efficiently by using integrating way. The researcher integrates reading and writing materials then creates them into digital flipping book application.

Reading and writing are closely related to cognitive activitiesthat are best taught using active or learner-centered processes. Learners shouldparticipate actively in language literacy skills of reading and writing. Reading and writing are vehicles for learning English as a second language.

Reference [17] reported a synthesis of research on reading andwriting relationships, finding that reading has an influence on writing and vice versa;hence, they concluded that these are cyclical and equally facilitative units thatsupport one another. Both reading and writing are manifestations of cognitive andlinguistic development.

According to the studies about integrating reading with other language skills; the reader needs to gather visual information from the written text (e.g., letters and words), identify the meaning of words, and then move forward to the processing of the structure and the meaning of larger syntactic units, such as phrases or sentences.

\section{METHODOLOGY}

This study uses Research and Development (R\&D), which to develop integrated materials of reading and writing. This study uses the combined stages of development that have been developed by reference [10]. The modified ADDIE model by researcher is the same as those models; Analyze, Design, Develop, Implement and Evaluate. The final product of these integrated materials of reading and writing is a digital flipping book application.

\section{RESULT, DISCUSSION AND PRODUCT DEVELOPMENT}

\subsection{Result of Need Analysis}

\subsubsection{Questionnaire}

The result of need analysis, by giving interviews and questionnaires are: The first point in target need is talking 
about students' knowledge. $69 \%$ of students answered they can understand the text and answered the questions well, $23 \%$ of 61 students can understand text well, and $3 \%$ of students answered cannot understand the text. One of the students answered that he cannot understand the text and answered the questions well.

The second point is talking about difficulties in learning reading and writing. In reading skill difficulties; $45 \%$ of students understand some vocabularies, $22 \%$ of students can understand the content of paragraph, $17 \%$ of students respond that they cannot understand the contents of paragraph, $15 \%$ of students said they cannot understand vocabularies and contents of paragraphs. In writing skill difficulties; $38 \%$ of students answered that they cannot understand many vocabularies, $23 \%$ from 61 students cannot create paragraphs in English, $17 \%$ of students cannot understand in both of vocabulary and create paragraphs, $20 \%$ of students answered understand much vocabulary but cannot create paragraphs in English.

The third point is talking about exercises in reading and writing. In reading skill; $71 \%$ of response from the students that they are given exercises to read text and answer the questions according to the text by teacher and $45 \%$ of response for students' like and wants, $21 \%$ of students answered they are given exercises to understand contents of news or article and $27 \%$ response for students' lacks and wants, $8 \%$ of students responded if they are given exercises to translate text into English and 27\% of response for students' lacks and wants. Meanwhile, in writing skill; $44 \%$ of students answered reading comprehension, according to the text and $33 \%$ of response for students' lacks and wants, $17 \%$ of respondents answered if they understand the contents of article and $37 \%$ of response for students' lacks and wants, 39\% of students translate text into English and $30 \%$ of response for students' lacks and wants. The exercises that students' like and students' want in reading and writing. $45 \%$ of respondents answered reading comprehension, $27 \%$ of students answered understanding the content of the article or news and translate into English.

The fourth point is talking about kinds of text that students' get in the classroom. $67 \%$ of students answered text or passages, $20 \%$ of student responses they had learned with article and $5 \%$ of responds for advertisement. $8 \%$ respondents answered they had learned announcement. On the other side, in writing $22 \%$ of respondents want to study about short stories, $24 \%$ of students respond that they want a study about the letter, $25 \%$ responding for announcements, and $17 \%$ response from the respondents show that they want to study about describing.

And for students' like and wants about reading text, 15\% of respondents want to study about novel, short story, comic, and text of dialogue. $50 \%$ of students like study to read text or paragraph, $25 \%$ of students answered that they like study to understand article and $10 \%$ of students respond like the study about advertisement. In writing the text, $33 \%$ of response shows that students like study in creating a short story, $18 \%$ of students answered that they want a study about creating and or analyzing letter, then $17 \%$ response for announcements.

The fifth point is the activity of the students in the classroom. $63 \%$ of students answered that they had studied reading in pair, $13 \%$ of respondents studied in group, $22 \%$ responding for individual. $20 \%$ of students respond that they want to study using computer application. In writing, $68 \%$ of students respond that they had learned writing according to their book, $5 \%$ response for slide media, $27 \%$ of respondents answered that they had learned in the paper. $50 \%$ response show that a half of students like study using their book. $23 \%$ of students answered that they like studying using slide media.

According to the fifth point of target need, this chart figured out the result of a target need in need analysis.

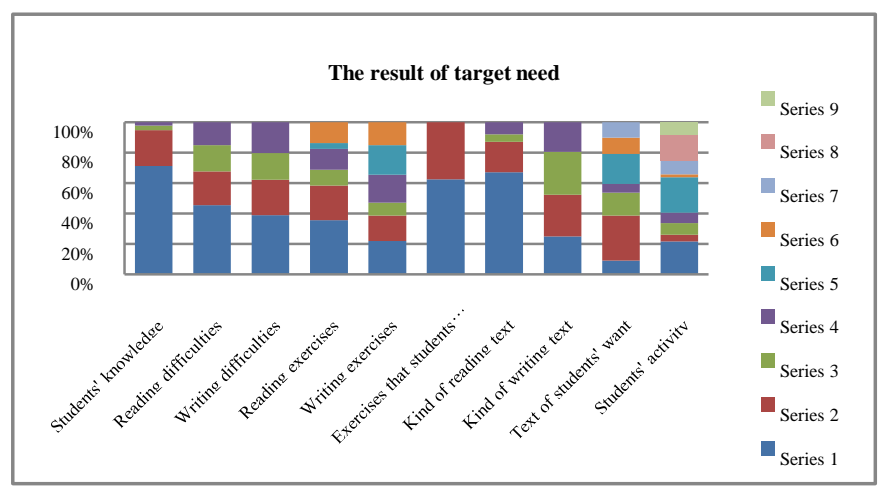

Chart 1. The result of target need

The first point in learning need is talking about the students' ability to use their English book. $25 \%$ response shows that students use their book, only in the learning process. Most of them used their book on the learning process, did homework, and at home (65\%), $8 \%$ of students answered that they used their book, only on learning process and did homework and only one student answered that she used her book in the classroom, English course and at home.

The second point is students' ability to use their gadget. Most of the students answered that they do not use their gadget while in the learning process. Meanwhile, 22\% from 61 students used their gadget in the learning process; online dictionary and Alfa link $® .70 \%$ of students responded that they use their gadget to study English outside activity, but others are not $(28 \%)$.

The third point is the frequency to use gadget for studying English. 59\% of students responded that they seldom used their gadget to studying English, 13\% response shows that students never used it, and $21 \%$ of students answered that they used only on learning process.

The fourth point is the use of computer application in reading and writing learning process. $52 \%$ of students 
responded that they had never used computer application to study in reading or writing, but the other had ever $(43 \%)$. Meanwhile, $68 \%$ from 61 students had never used digital flipping book to study reading or writing, but others had ever (29\%). They operate Hello America, Adobe PDF Reader. 59\% response shows that students will use this program individually, $25 \%$ in group and $14 \%$ in pair. For the installations of this computer application, it shows that $70 \%$ of students will install on their Smartphone, $17 \%$ of students will install in their laptop and $11 \%$ of students' in PC/computer.

The fifth point is the content of the book application of reading and writing. $61 \%$ of respondents prefer one chapter consist of material and exercises than material and exercises in separately (28\%).

The sixth point is the advantages of using computer application. $67 \%$ response shows that students can use application anywhere and anytime, $28 \%$ of students say they can study using their gadget.

According to the sixth point of learning needs, this chart figured out the result of learning need in need analysis.

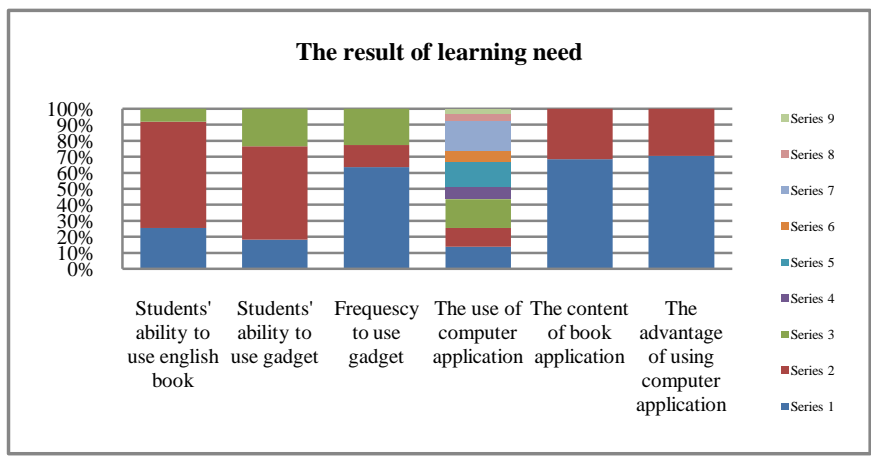

Chart 2. The result of learning need

\subsubsection{Interview}

The researcher interviews English teacher of SMPN 4 Gresik of A and B Class at eighthgrade (Nurul Budi Priwarti, S.Pd). The purpose of interview is to know how the teacher teaches her students about reading and writing in the classroom.

The first point, strategy that is used by teacher in teaching reading is problem and solving. She considers that her students have less ability in speaking; she wants that students can answer the problem which is given by teacher orally. The aim of that way is for students to be able to speak fluently. She told the students to understand the problem in three to five minutes then asked them to answer teacher's questions orally. She also used it in teaching writing but she asked students to resume in the paragraph and created story according to material of that day and found out the main idea in every paragraph. She conducted the whole activities individually.
Media are used by teacher in teaching reading and writing. The teacher used projected still media; slide/LCD projector. But it is used related to the materials, such as; video about asking and giving information. Teacher often uses students' book in teaching reading and writing, then gives a students' assignment orally and written. This condition is not really good because language laboratory of this school is still in reparation.

The difficulty in teaching reading; students have less vocabulary so they cannot understand the story correctly, completely and as fast as possible. According to the teacher, in teaching writing; the difficulty is students cannot understand the generic structure in creating paragraph to be a story or generic structure of how the way to describe things and or animals and students have less vocabulary it makes students difficult to write in English text whether answering or translating and also, they need dictionary to create it.

The way how to reach students' reading and writing skill are asking them to paraphrase the story, then resume it and find main idea of every paragraph. The teacher said that this way it can reach students' vocabularies and comprehending English text.

The teacher had ever taught students by using a power point application, but she never taught by using program and computer application to teach reading and writing in the classroom. But she is ready to permit student uses their mobile phone or other mobile storage in a learning activity.

Based on the result of questionnaire and interview above, there are five points for discussion (prototype). The first is aim, which focuses on integrating materials of reading and writing. The materials and exercises will be integrated in one chapter.

The second is content. In this point, it consists of two sub-point discussion; types of text and material. Student prefers learning reading in paragraph, article and advertisement, then learning writing in short story, letters, announcement, describing and article. Meanwhile, in materials, according to students' book: describing things and animals, my gorgeous idol, wonderful places, my unforgettable holiday, my first experience.

The third is learners' background. Most of the students answered that they have less vocabulary and understanding in contents of the paragraph, then they have difficulties to do exercises in reading comprehension or find out the main idea of some stories. In writing, students cannot understand much vocabulary so they cannot create a paragraph or story in English.

The fourth point is learners' interest. The first subpoint is exercised, related to the second point; student prefers to do reading comprehension in reading or writing. The 
second sub-point is activity; group activity is the favorite activity that they did then followed by individual and pair activity. The third sub-point is the media; student prefers study in using their book.

\subsection{Developing the Product}

This phase is stage where the concrete steps and need analysis results which have been summarized in prototype developed with eighth grade syllabus into three chapters for eighth grade of junior high school. Those three chapters have been developed well and followed the implementation of project-based learning approach. This application can be used to users' gadget, laptop or pc and this can be operated everywhere and anywhere.

The following describes of chapter 1 of this application, which contains of three sub chapters; invitation, announcement, and advertisement.
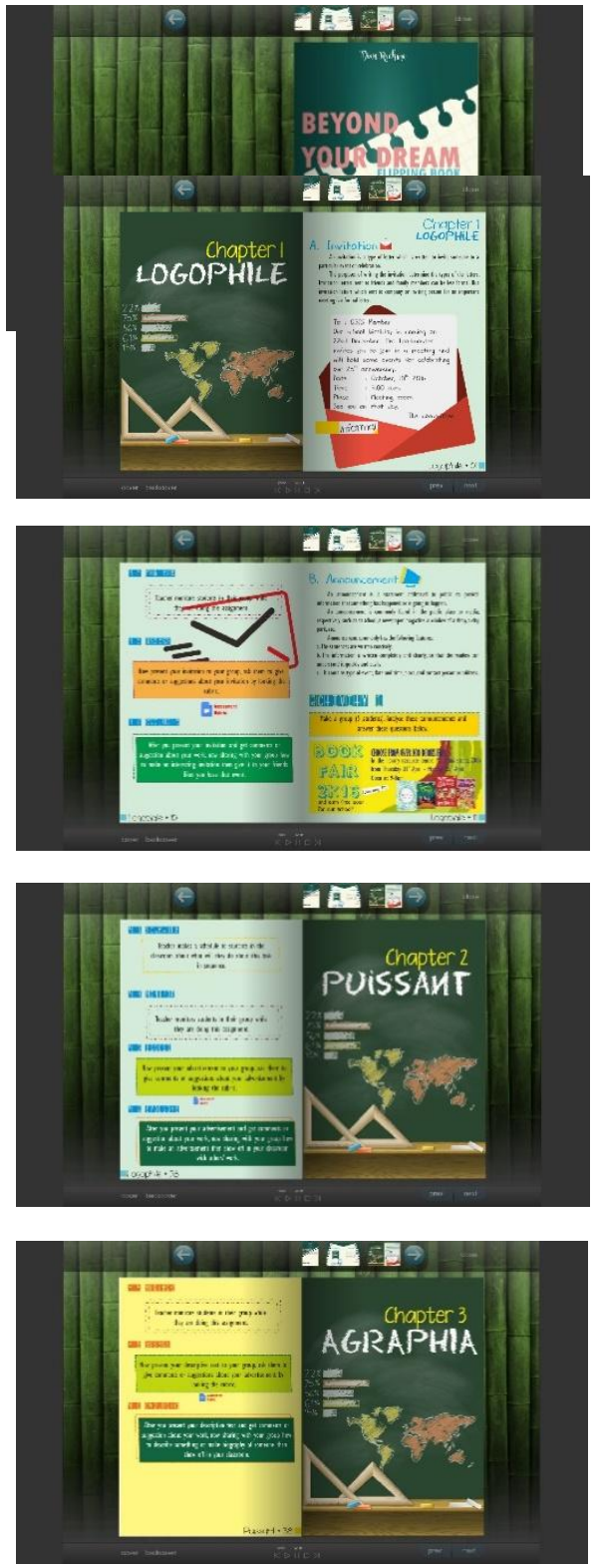

Figure 1.Chapters of digital flipping book
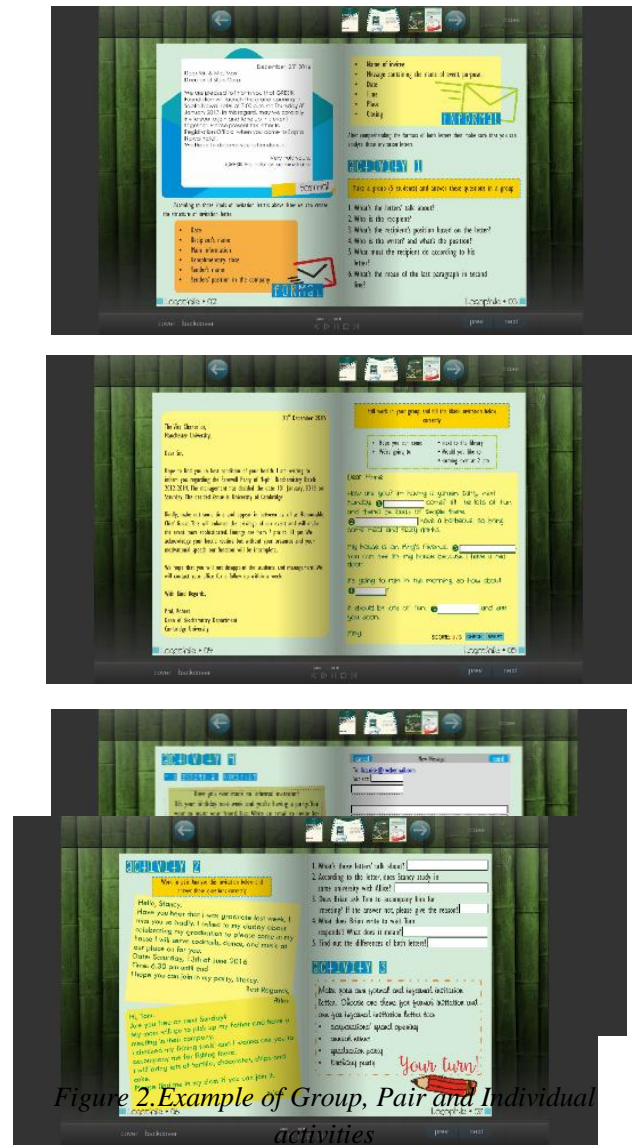

Figure 3.Example of Project-based activities

After describing the product of digital flipping book application based on prototype and need analysis, each chapter has four main activities; group activities, pair activities, individual activities and project-based activities. It can be concluded that group activities in every chapter are pre-task activities, pair and individual activities are whilst task and project-based activities are the post task activities.

\section{CONCLUSION AND RECOMMENDATION 4.1 Conclusion}

The previous researcher concluded that; first, theoutdated lists contain programs that are not tools for the meaningful integration of computer into instruction. Second, the majority of theprograms are no instructions; they do not track student progress, providefeedback, or adapt to suit student needs, thereby limiting their usefulness aseducational tool. Digital flipping book was developed based on students' need and has feedback to students. This application has materials and exercises also assessment rubric. Students can do all exercises in the digital flipping book; input text, multiple choices, true and false, and reading comprehension. They can assess their 
friend's tasks according to the assessment rubric there. The interesting side of this digital flipping book is that students can listen to the music while they are operating this application in the learning process.

\subsection{Recommendation}

For other researchers: They should have a deeper understanding about project based learning approach and create materials which are more interesting with the exercises, setting, and activities that correspond to the students' need and the students' profile also they should give more materials in reading.

For the English teacher: Because the teachers only provide suitable materials, the English teachers should have creativity and innovation in combining the materials in the learning materials with the teaching and learning process in the classroom. Also, the English teacher should have other learning application program to make students interested in learning inside or outside the class.

\section{ACKNOWLEDGMENT}

I thank to Mr. Khoirul Anwar and Mr. Candra Hadi Asmara for their suggestions to improve this article.

\section{REFERENCES}

[1] Aldoobie, N. 2015. ADDIE Model. American International Journal of Contemporary Research, Vol. 5, No. 6, December 2015.

[2] Almehi, M.A. 2014. Effects of Teaching Argumentative Reading and Writing by Integration in an E-Learning Environment on Literacy Development in EFL College Students. International Journal of Humanities and Social Science, Vol.4, No. 5, March 2015.

[3] Bastias, M., Elena, E., Munoz, S., \& Lorena, M. 2011. Integration of the Four Skills of the English Language and Its Influence on the Performance of Second Grade High School Students. A journal presented on Seminario para optar al titulo de professor de education media en ingles of Universidad Del Bio-Bio. Chile, 2011.

[4] Bouton, D.G. CorelDRA $W^{\circledR} X 4$ : The Official Guide. Corel Corporation. 2008

[5] Brown, H.D. 2000. Teaching by Principles: AnInteractive Approach to Language Pedagogy. Second Edition. NY: Pearson Education

[6] Cho, H. \& Brutt-Griffler, J. 2015. Integrated reading and writing: A case of Korean English language learners. Reading in a Foreign Language, Vol. 27, No. 2, pp. 242-261, October 2015

[7] Dick, W., Carey, L., \& Carey, J.O. (2001). The systematic design of instruction $\left(5^{\text {th }}\right.$ ed.). Allyn \& Bacon, p. 2 .

[8] Dick, W., Carey, L., \& Carey, J.O. (2005). The systematic design of instruction (6 ed.). Boston: Pearson/Allyn and Bacon.
[9] Durukan, E. 2011. Effects of cooperative integrated reading and composition (CIRC) technique on reading-writing skills. Educational Research and Reviews, Vol. 6(1), pp. 102-109, January 2011. http://www.academicjournals.org/

[10] Gall, M.D., Gall, J.P., \& Borg, W. R. Educational Research an Introduction; Third Edition (USA: Pearson Education, 1983), p. 772

[11] Gall, M, D., Gall, J.P., \& Borg, W. R. Educational Research an Introduction; Third Edition (USA: Pearson Education, 1983), p.775-776

[12] Giesen, L. 2001. Activities for Integrating Reading and Writing in the Language Classroom. Vermont: Master of Arts in teaching degree.

[13] Goen, S. \& Tropp-G. H. 2013. Integrating Reading and Writing: A Response to the Basic Writing "Crisis". Journal of Basic Writing, Vol. 22, No. 2, 2013.

[14] Haq, A. 2016. Developing English Reading Material Using Content Based Instruction Approach for Tenth Grade Students of Automotive Department at SMKN 1 Sidayu in the First Semester :Unpublished Thesis.

[15] Harun, D.H.Y. 2006. Project-Based Learning Handbook "Educating the Millennial Learner". Educational Technology Division. Malaysia.

[16] Hill, G.M. Writing Assessment and Evaluation Rubrics Grade 6. Columbus, $\mathrm{OH}$

[17] Hunchinson, T. \& Waters, A. 1987. English for Spesific Purpose: A Learning - Centered Approach. UK. Cambridge University Press.

[18] Kasemsap, B. \& Lee, Y.H. Hugo. L2 Reading in Thailand: Vocational College Students' Application of Reading Strategies to their Reading of English Texts. The Reading Matrix: an International Online Journal, Vol. 15, No. 2, September 2015

[19] Linh, N.D. \& Suppasetseree, S.. The Development of an Instructional Design Model on Facebook Based Collaborative Learning to Enhance EFL Students' Writing Skills. Suranaree University of Technology, Thailand.

[20] Lovell, M. \& Phillips, L. 2009. Commercial Software Programs Approved for Teaching Reading and Writing in the Primary Grade: Another Sobering Reality. Journal of Research on Technology in Education, 42(2), 197-216.

[21] Mmela, E. 2006. Implementing Integrated Literacy Approaches in an English Classroom in Malawi. Virginia: The degree of Doctor of Philosophy.

[22] Morrison, G.R., Ross, S.M., \& Kemp, J.E. (2004). Designing effective instruction ( $4^{\text {th }}$ ed.). Hoboken, NJ: John Wiley \& Sons, Inc, p. 29.

[23] Morrison, G.R., Ross, S.M., \& Kemp, J.E. (2007). Designing effective instruction (5th Ed.). Hoboken, NJ: Jonh Wiley \& Sons, Inc.

[24] Nurhidayat, T. 2011. Students' Ability in Writing

[25] Recount Based on Generic Structure, Language Features and Social Function.: Unpublished Thesis.

[26] Recount Text: http://englishwithgalih.blogspot.com/2014/01/listof-examples-recounttext.html. Retrieved on November $15^{\text {th }}, 2016$. 
[27] Shen, M-Y. 2009. Reading-Writing Connection for EFL College Learners' Literacy Development. The Asian EFL Journal Quarterly, 11(1), 87-106.

[28] Songhori, M. 2008. Introduction to Needs Analysis. English for Specific Purposes world, Issue 4.

[29] Sunggingwati, D. \& Nguyen, T.H. 2013. Teachers' Questioning in Reading Lessons: A Case Study in Indonesia. Electronic Journal of Foreign Language Teaching 2013, Vol. 10, No. 1, pp. 80-95.

[30] Suppasetseree, S. (2005). The development of an internet-based instructional system for teaching remedial English to first-year university students.Thailand, SuranareeUniversity of Technology.

[31] Ulrich, K. \& Sharp, W. (Ed). 2006. Visual QuickStart Guide: Macromedia Flash 8 for Windows and Macintosh. Peachpit Press.

[32] Utami, T.A.A. 2014. Improving The Ability in Writing Descriptive Texts Through Brainstorming Technique for Grade VIII Students at SMP N 1 Piyungan : Unpublished Thesis

[33] Writing Skill Practice: www.britishcouncil.org/learninglishteens. 2012. The British Council. Retrieved on November $15^{\text {th }}, 2016$. 